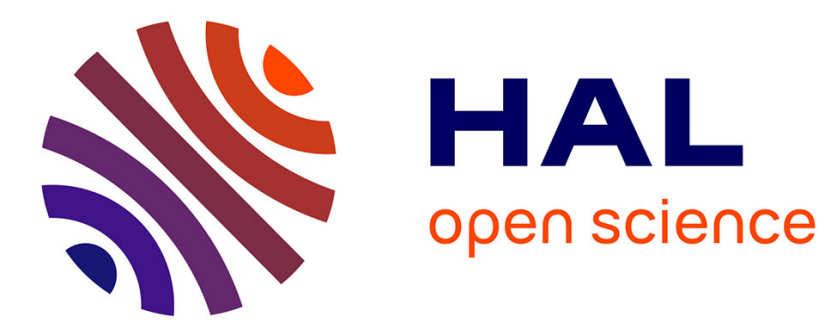

\title{
Pressuremeter test parameters of a compacted illitic soil under thermal cycling
}

\author{
H. Eslami, S. Rosin-Paumier, Adel Abdallah, F. Masrouri
}

\section{To cite this version:}

H. Eslami, S. Rosin-Paumier, Adel Abdallah, F. Masrouri. Pressuremeter test parameters of a compacted illitic soil under thermal cycling. Acta Geotechnica, 2017, 12 (5), pp.1105-1118. 10.1007/s11440-017-0552-2 . hal-01717739

\section{HAL Id: hal-01717739 \\ https://hal.science/hal-01717739}

Submitted on 18 Jun 2018

HAL is a multi-disciplinary open access archive for the deposit and dissemination of scientific research documents, whether they are published or not. The documents may come from teaching and research institutions in France or abroad, or from public or private research centers.
L'archive ouverte pluridisciplinaire $\mathbf{H A L}$, est destinée au dépôt et à la diffusion de documents scientifiques de niveau recherche, publiés ou non, émanant des établissements d'enseignement et de recherche français ou étrangers, des laboratoires publics ou privés. 


\title{
Pressuremeter test parameters of a compacted illitic soil under thermal cycling
}

\author{
Eslami, H. ${ }^{\mathrm{a}, \mathrm{b}}$, Rosin-Paumier, S. ${ }^{\mathrm{a}}$, Abdallah, A. ${ }^{\mathrm{a}}$, Masrouri, F. ${ }^{\mathrm{a}}$ \\ ${ }^{a}$ LEMTA (CNRS, UMR 7563), Université de Lorraine, Vandoeuvre-lès-Nancy, France ; \\ ${ }^{b}$ ESITC de Metz, Metz, France \\ *Corresponding author: hossein.eslami@univ-lorraine.fr \\ sandrine.rosin@univ-lorraine.fr \\ adel.abdallah@univ-lorraine.fr \\ farimah.masrouri@univ-lorraine.fr
}

Postal address: LEMTA, Bâtiment E, 2 rue du Doyen Marcel Roubault, TSA 70605, 54518 Vandoeuvre-lès-Nancy, France

ABSTRACT: The incorporation of heat exchangers into geostructures leads to changes in the temperature of the adjacent soil. Important issues arise about the effect of temperature variations on hydro-mechanical soil behaviour. The objective of this paper is to improve the understanding and the quantification of the impact of temperature variation on the bearing capacity of thermo-active piles. Currently, the design of the deep foundations is based on the results of in situ penetrometer or pressuremeter tests while there is no published data on the effect of temperature on in situ tests results allowing to specifically assess thermo-active piles behaviour. Herein, an experimental device is developed to carry out mini-pressuremeter tests under controlled laboratory conditions. Mini-pressuremeter tests are performed on an illitic soil in a thermoregulated metric scale container subjected to a range of temperature from 1 to $40{ }^{\circ} \mathrm{C}$. The results showed a slight decrease in the pressuremeter modulus $\left(E_{p}\right)$ and a significant decrease in the creep pressure $\left(p_{f}\right)$ and the limit pressure $\left(p_{l}\right)$ as the temperature 
increased. The results showed also the reversibility of this effect during a heatingcooling cycle through the investigated temperature range, while the effect of a coolingheating cycle was only partially reversible. In the case of several thermal cycles, the effect of the first cycle proved to be decisive on the soil parameters.

Keywords: Laboratory tests; Pressuremeter; Temperature; Compacted soils; Illite.

\section{Introduction}

In the last years, developments in the field of shallow geothermal energy systems using geostructures such as thermal piles, diaphragm walls, tunnel linings, basement slabs are being achieved (Brandl, 2006; Fromentin et al., 1999; Laloui et al., 2003). These thermo-active elements in contact with the subsurface soil are used to inject heat in the summer and/or extract heat in the winter. Under service conditions, the temperature of the heat exchanger fluid within the pipes is generally between 4 and $30{ }^{\circ} \mathrm{C}$ (Péron et al., 2011) and the circulation of the fluid results in cyclic changes in the surrounding ground temperature.

In the case of energy piles, on one hand, the thermal expansion or contraction causes additional thermal stresses in the pile which can influence the skin friction and the end bearing and consequently the load transfer (Arairo et al., 2015; Bourne-Webb et al., 2013). On the other hand, the cyclic thermal variation imposed to the soil may affect its hydro-mechanical properties. Thus, the behaviour of an energy pile is directly related to the coupling of thermal, hydraulic and mechanical phenomena. Under thermal conditions, the soil properties such as thermal conductivity, heat capacity, density, water content and hydraulic conductivity could be modified. These modifications may affect the bearing capacity as well as the friction behaviour of the soil. To study the temperature effect on ground structures, the complex interactions between temperature 
variations and induced stresses and strains, which may affect long-term structure performance, must be considered (McCartney et al., 2010a). Despite the growing number of energy piles (Brandl, 2006), only few recommendations are published (e.g. GSHP Association, 2012), there is still no standard for the design of this type of piles.

Different studies were conducted on the behaviour of energy piles and their thermomechanical response in situ (Akrouch et al., 2014; Bourne-Webb et al., 2009; Laloui et al., 2003) and in laboratory (McCartney et al., 2010b; Tang et al., 2013). All these studies focused on the pile behavior and the effect of temperature variations on the soil parameters has been completely neglected although, a cyclic thermal variation may have an important impact on the shear strength, yielding and critical-state soil properties. Especially, the contraction of the elastic domain (yield locus) with the increasing temperature has been shown in the literature for various clay materials. Several relevant studies addressing the so-called thermal softening are cited in Table 1. However, to take into account these evolutions, it is necessary: (1) to connect the surrounding soil parameters to the soil-pile mechanical interaction behavior, (2) to study the effect of lowest and highest temperatures and (3) to consider the influence of cyclic evolution of the temperature. In this paper, the impact of cyclic thermal variations in the range from 1 to $40{ }^{\circ} \mathrm{C}$ on the parameters which are directly linked to the soil bearing and to the soil-pile friction is quantified.

Calculation of the bearing capacity of deep foundations are currently based on pressuremeter or/and penetrometer test results (AFNOR, 2000, 1996; Standard ASTM, 1999, 1995). Eslami et al. (2015) studied the effect of temperature variation on penetration test parameters in two compacted soils but there is still no available data on the effect of temperature on the pressuremeter parameters. Thus, herein and for the first time, a mini-pressuremeter test adapted to laboratory conditions is used to quantify the 
temperature effect on the mechanical behavior of the soil. An experimental method is developed to carry out mini-pressuremeter tests on an homogeneous soil compacted at a controlled density and water content and subjected to monotonous or cyclic thermal variations.

In the following sections, first the material preparation and the experimental device are described, then, the obtained results are presented and the effect of temperature variations on the pressuremeter parameters is discussed.

\section{Material and methods}

In this section, the studied material is presented and experimental device and the minipressuremeter tests are detailed.

\subsection{Basic characterisation of the material}

The tested material is an illitic soil named Arginotech ${ }^{\circledR}$ from the east of Germany. It contains $77 \%$ illite, $10 \%$ kaolinite, $12 \%$ calcite and traces of quartz and feldspar. Illite is a non-swelling clay found in various proportions in soils due to the illitization of several minerals (Lynch, 1997). Mini-penetration tests, conducted on this soil by Eslami et al. (2015) showed the sensitivity of this material to temperature variations.

The particle-size distribution of the soil was determined using a laser Malvern Mastersizer $2000 \AA$ device (Figure 1a). Almost $85 \%$ of the particles of the illitic material are smaller than $0.002 \mathrm{~mm}$ (clay particles), and the remaining $15 \%$ are smaller than $0.02 \mathrm{~mm}$ (silt particles). Its liquid limit (LL) is $65 \%$, the plastic limit (PL) is $34 \%$, and the plasticity index (PI) reaches 31 (AFNOR, 1993). The obtained standard Proctor curve of the material (AFNOR, 1999) allows defining an optimum water content of $31.3 \%$ and a maximum dry density of $1.43 \mathrm{Mg} / \mathrm{m}^{3}$ (Figure $1 \mathrm{~b}$ ). The material is classified 
as "A3" in the French standard for soil classification (GTR, 2000) and as a fat clay, MH, according to the Unified Soil Classification System (Standard ASTM, 2006).

\subsection{Experimental device and methods}

To perform mini-pressuremeter tests under controlled temperatures, a homogeneous soil with a relatively large volume is required as well as an experimental device to impose thermal variations to the soil. In this section, the developed methodology to obtain a meter-scale sample with homogeneous properties (temperature, water content and dry densities) is described.

\subsubsection{The container}

A cylindrical stainless steel container of $800 \mathrm{~mm}$ in height and $600 \mathrm{~mm}$ in diameter is made. A stainless steel tube is welded to the outside of the container. This tube is connected to a Vulcatherm® thermoregulator to allow the circulation of an ethylene glycol-water solution at the target temperature in the tube $\left(-20\right.$ to $\left.90{ }^{\circ} \mathrm{C}\right)$. As a result, the soil, compacted in the container, is heated or cooled from the outer lateral surface of the container. The evolution of the temperature within the sample is centripetal. Insulating sleeves are placed on the tube to reduce heat exchange with the surrounding atmosphere. The top of the massif is insulated with a plastic film to preserve the initial water content. Finally, the whole device is placed in a box made of extruded polystyrene plates of $40 \mathrm{~mm}$ thick to reinforce the insulation (Figure 2).

\subsubsection{Sample preparation and compaction}

First of all, the required amount of water is added to material ( $\left.w_{\text {initial }} \cong 17 \%\right)$ in a large capacity fixed-speed $(38 \mathrm{rpm})$ mixer MIX120® to reach the target water content: $w_{\mathrm{OPN}}=31.3 \%$ (Figure $3 \mathrm{a}$ ). The wet material is stored in 8 plastic drums for a minimum 
period of 5 days to ensure a good homogenization. A pneumatic compactor is used to compact the material in the container in several layers at ambient temperature (approximately $20^{\circ} \mathrm{C}$ ). The compactor applied dynamic forces on a metallic plate of $4 \mathrm{~mm}$ in thick and $600 \mathrm{~mm}$ in diameter to allow a homogeneous compaction of the soil. The volume of each layer is controlled by three rulers fixed to the inside wall of the container (Figure 3b).

Two compaction processes were tested: (1) a compaction in 8 layers of $100 \mathrm{~mm}$ in thickness and (2) a compaction in 11 layers of $70 \mathrm{~mm}$ in thickness. The two processes were tested and the resulting dry density evolution according to the depth was checked thanks to the extraction of several soil cores. Results of these tests, presented in section 3.1, led to the choice of a compaction in 11 layers of $70 \mathrm{~mm}$ in thickness for all test series.

\subsubsection{Instrumentation of the sample}

Seven thermal sensors PT100 are positioned within the soil at various depths and various distances from the wall of the container as shown in Figure 4. The sensors are plugged to a data logger to monitor the temperature evolution inside the compacted soil during the heating/cooling phases.

\subsection{Mini-pressuremeter tests}

Only six mini-pressuremeter tests are performed in each massif to prevent edge effects and cross-influence between the tests. The test points are positioned on a concentric circle twice smaller than the container. The tests are carried out at $150 \mathrm{~mm}$ from the edge of the container and the distance between the test points is also150 $\mathrm{mm}$ (Figure 5). All test points have the same position so that the results can be compared. The pressuremeter tests are conducted with an APAGEO® mini-pressuremeter probe of 380 
$\mathrm{mm}$ in height and $28 \mathrm{~mm}$ in diameter (Figure 6). Before each pressuremeter test, a core with a diameter equal to that of the mini-pressuremeter probe is extracted using a core sampler. The $630 \mathrm{~mm}$ core is divided into small pieces to measure the water content and the density of the material as a function of the depth. The center of the probe is positioned in the middle of the height of the compacted soil $(385 \mathrm{~mm})$. The probe is connected to a pressure-volume controller GDS®. The pressure controlled test consists in applying increasing pressure with equal increments of $25 \mathrm{kPa}$ for at least one minute. The equilibrium injected volume is measured for each increment and the volume versus pressure curve is plotted. The test is stopped when the injected volume reached $140,000 \mathrm{~mm}^{3}$ (the volume variation limit of the probe). Immediately after the pressuremeter test at a given temperature, the borehole is filled up with the same material, at the same water content, to avoid influencing the following tests. In this study, the effect of temperature variations on the resistance of the mini-pressuremeter membrane is measured by placing the probe in a climatic chamber at a given temperature during the calibration test of the membrane resistance. Figure 7 shows the developed experimental device elements for the mini-pressuremeter tests.

\section{Results}

In the framework of this study, a preliminary series and four test series (six minipressuremeter tests for each series) were carried out (Table 2). The preliminary series aimed to check the efficiency and repeatability of the compaction method to obtain a homogeneous massif (water content and dry density). It also enabled to assess the reproducibility of the mini-pressuremeter tests performed in the soil and to estimate the related uncertainties of the test parameters. The four following test series quantified the effect of a monotonic or a cyclic thermal variation on the pressuremeter parameters. The 
performed tests in each sample were numbered as follows $\mathrm{Xx}$; with $\mathrm{X}$, the massif temperature when performing test (i.e. 1,20 or $40{ }^{\circ} \mathrm{C}$ ) and $\mathrm{x}$, a letter indexing the test that increments for each new test at the same temperature.

In the following, the preliminary series will be presented. Then we focus on the evolution over one thermal cycle by studying the first and the second series. Finally we conclude on the impact of several thermal cycles by analysing the results of the third and the fourth test series.

\subsection{Preliminary series}

The preliminary test series, carried out at $20{ }^{\circ} \mathrm{C}$, aimed to verify the homogeneity of compacted soil (Figure 8), as described in section 2.2.2. Figure 8a shows the variation of the dry density versus depth for a soil compacted in 8 layers of $100 \mathrm{~mm}$. In each layer, $\rho_{d}$ is $7 \%$ higher than the target at the top of the layer, and $6 \%$ lower than the target value at the bottom of the layer. This density gradient was measured within each layer and the soil is heterogeneous. Figure $8 b$ shows the dry density profile when the soil is compacted in 11 layers of $70 \mathrm{~mm}\left(4^{\text {th }}\right.$ test series $)$. As it was expected, the gradient of $\rho_{d}$ decreased significantly, the values were closer to the target value (in average $\pm 2.5 \%$ ). Thus, having fixed the accuracy of the dry density to 5\%, the compaction in 11 layers of $70 \mathrm{~mm}$ in thickness was chosen for the preparation of the soil studied in the following test series.

Five mini-pressuremeter tests were performed for the preliminary series under the same conditions (Figure 9). Each pressuremeter curve consists in 3 domains: (i) the probe inflates to achieve the contact with the wall of the hole, (ii) the volume increases linearly with increasing pressure allowing the calculation of the pressuremeter modulus $E_{p}$ (the soil pseudo-elastic reaction against the probe pressure) and (iii) large 
displacements take place and the soil becomes plastic. The creep pressure $\left(p_{f}\right)$ is in the boundary between the second and the third domain of the curve. The pressuremeter parameters $\left(E_{p}, p_{f}, p_{l}\right)$ were determined from the pressuremeter curves (Table 3$)$. The results showed a good repeatability of the tests and allowed the estimation of the uncertainty of each parameter according to the Student's t-distribution (because of the limited number of measurements) for a $90 \%$ confidence interval: $E_{p}: \pm 10 \%, p_{f}: \pm 5 \%$, $p_{l}: \pm 5 \%$.

\subsection{Effect of one thermal cycle}

To quantify the impact of temperature variations on pressuremeter parameters, two test series were carried out. In this part, each test series is explained then results are compared.

\subsubsection{First series: heating-cooling cycle $\left(20-40-20^{\circ} \mathrm{C}\right)$}

For the first test series, starting from $20^{\circ} \mathrm{C}$, the soil was heated to $40{ }^{\circ} \mathrm{C}$ and then cooled to $20{ }^{\circ} \mathrm{C}$ at the end. Figure 10 shows the temperature variation as recorded by the sensor S5 located at $150 \mathrm{~mm}$ from the edge of the massif and at the middle of its height (Figure 4). The thermal equilibrium within the limits of $\pm 1{ }^{\circ} \mathrm{C}$ was reached after $65 \mathrm{~h}$.

The average water content of the soil close to the test area (from 200 to $580 \mathrm{~mm}$ in depth) was measured (Table 4). At $40{ }^{\circ} \mathrm{C}, w$ was slightly lower than at $20^{\circ} \mathrm{C}$, this might be due to: (1) the evaporation of water during the core drilling and the sample weighting or/and (2) an heterogeneity of the soil. According to the location of the successive tests (Figure 5), the first hypothesis is most likely. The average dry densities were almost identical, confirming the homogeneity of this parameter over the massif. 
Two mini-pressuremeter tests were performed at each temperature step: $20 \mathrm{a}$, $20 \mathrm{~b}$, then $40 \mathrm{a}, 40 \mathrm{~b}$ and finally $20 \mathrm{c}, 20 \mathrm{~d}$. The test $20 \mathrm{a}$ failed due to a membrane leakage. The results of the five other tests are presented in Figure 11.

The evaluation of the pressuremeter parameters $\left(E_{p}, p_{l}\right.$ and $\left.p_{f}\right)$, allowed the quantitative comparison of the tests at different temperatures (Table 4). The values of $p_{f}$ and $p_{l}$ decreased significantly when the massif was heated to $40{ }^{\circ} \mathrm{C}$. Thus, the soil was yielded under lower pressures at $40{ }^{\circ} \mathrm{C}$ than at $20{ }^{\circ} \mathrm{C}$. In other words, the results showed a softening of the soil with heating. The pressuremeter parameters for $20 \mathrm{~b}$ and $20 \mathrm{c}-\mathrm{d}$, tests after decreasing the temperature from 40 to $20{ }^{\circ} \mathrm{C}$, were close, which showed a good reversibility of the effect of the temperature variation in the range of $20-40{ }^{\circ} \mathrm{C}$. The softening due to the heating and the reversibility of the observed effects on the creep pressure and the pressure limit were also noticed on the pressuremeter modulus $\left(E_{p}\right)$ to a lower extent.

\subsubsection{Second series: cooling-heating cycle $\left(20-1-20^{\circ} \mathrm{C}\right)$}

For the second series, the soil was compacted and then successively brought from $20{ }^{\circ} \mathrm{C}$ to $1{ }^{\circ} \mathrm{C}$ and then again to $20{ }^{\circ} \mathrm{C}$. The average water content at the test depth varied from $30.8 \%$ to $32.6 \%$. This variation shows the homogeneity of the water content within the massif. The average dry densities vary from 1.21 to $1.43 \mathrm{Mg} / \mathrm{m}^{3}$. Figure 12 shows the temperature evolution in the massif as measured by sensor S5 (Figure 4). After temperature equilibrium, two pressuremeter tests were conducted at the end of each temperature step. The results of the six tests are shown in Figure 13.

The mini-pressuremeter curves presented three domains as with the others minipressuremeter curves but, on the contrary to the heating tests (cf. 3.2.1), the cooling to $1{ }^{\circ} \mathrm{C}$ leads to a hardening of the soil. Thus, the pseudo-elastic domain was longer in the 
case of the tests at $1{ }^{\circ} \mathrm{C}$ and the parameters $p_{f}, p_{l}$ and $E_{p}$ increased (Table 5). When the temperature raised back to $20{ }^{\circ} \mathrm{C}(20 \mathrm{~g}$ and $20 \mathrm{~h})$, the obtained parameters decreased back but remained slightly higher than those given by tests 20e and 20f (before cooling). Thus, only a partial reversibility of the impact of the temperature variation was observed: the material appears to be definitely affected by the cooling phase to $1{ }^{\circ} \mathrm{C}$.

\subsubsection{First and second series comparison}

The first two series of heating test $\left(20-40-20^{\circ} \mathrm{C}\right)$ and cooling test $\left(20-1-20^{\circ} \mathrm{C}\right)$ were used to study the effect of one temperature cycle. The preparation of a massif of $0.22 \mathrm{~m}^{3}$ made it difficult to obtain exactly the same initial conditions in these two test series. Thus, the obtained values for the first tests at $20^{\circ} \mathrm{C}$ of both test series $(20 \mathrm{~b}, 20 \mathrm{e}$ and 20f) were different. To compare these tests, the average values obtained at the end of the first step at $20^{\circ} \mathrm{C}, \overline{E_{p}}(20), \overline{p_{f}}(20)$ and $\overline{p_{l}}(20)$, were considered as reference values and the other values were normalized with respect to the reference values according to the equations (1), (2) and (3).

$$
\begin{gathered}
E_{n . p}=\frac{E_{p}(T)}{\overline{E_{p}}(20)} \\
p_{n . f}=\frac{p_{f}(T)}{\overline{p_{f}}(20)} \\
p_{n . l}=\frac{p_{l}(T)}{\overline{p_{l}}(20)}
\end{gathered}
$$

Figure 14 shows the evolution of the normalized parameters at each step of each test series. The initial values at $20^{\circ} \mathrm{C}$, used as references, were close to 1.0 and the studied parameters decreased as temperature increased. The temperature effect was more pronounced for $p_{n . f}$ and $p_{n . l}$ than $E_{n}$. Cooling cycle evidenced the partial reversibility of the hardening. The values of $p_{n . f}$ increased by $30 \%$ as the soil was cooled 
from 20 to $1{ }^{\circ} \mathrm{C}$ while it decreased by $7 \%$ as temperature reduced to $20{ }^{\circ} \mathrm{C}$ (Table 6). In the same way, $p_{n . l}$ increased by $21 \%$ with cooling then decreased by $9 \%$ with returning to $20{ }^{\circ} \mathrm{C}$.

Heating cycle evidenced the reversibility of the thermal softening. Heating the soil from 20 to $40{ }^{\circ} \mathrm{C}$ decreased $p_{n . f}$ by $15 \%$, while returning back to $20{ }^{\circ} \mathrm{C}$ increased it by $13 \%$. In the same manner, $p_{n . l}$ decreased by $14 \%$ with heating and increased by $20 \%$ with returning to $20^{\circ} \mathrm{C}$.

\subsection{Effect of several temperature cycles}

The third and fourth test series, carried out on different massifs consisted in tests at 20, 1 and $40{ }^{\circ} \mathrm{C}$. The initial temperature was $20^{\circ} \mathrm{C}$ and the massif was brought to 1 and $40{ }^{\circ} \mathrm{C}$ successively completing three cooling-heating cycles, each heating or cooling step lasting at least 70 hours (Figure 15 and Figure 16). The thermal equilibrium was reached for each step before performing the mini-pressuremeter test.

Table 7 and Table 8 present all the obtained parameters and properties. The average water contents and the average dry densities variations according to the thermal solicitation were lower than $1 \%$ : the massifs were homogeneous.

The mini-pressuremeter tests were conducted at the end of the selected steps as shown in the Figure 15 and Figure 16. The pressuremeter curves (Figure 17 and Figure 18) were consistent with the three pressuremeter domains. In agreement with the previous series, a softening took place after heating the soil to $40{ }^{\circ} \mathrm{C}$ and a hardening was observed after cooling it to $1{ }^{\circ} \mathrm{C}$, whatever the order of testing.

The pressuremeter parameters were calculated at each step of each series and presented in Figure 19. Over the third series, the $p_{f}$ value increased slightly with cooling the massif from 20 to $1{ }^{\circ} \mathrm{C}$, then it remained almost constant with heating/cooling 
cycles $\left(1-40-1^{\circ} \mathrm{C}\right)$. The $p_{l}$ values increased with heating and decreased with cooling, these results were consistent with those of the previous test series. Over the fourth series, the first pressuremeter test at $20{ }^{\circ} \mathrm{C}$ was inoperable and the corresponding values in Figure 19 were estimated assuming similarity between the $3^{\text {rd }}$ and the $4^{\text {th }}$ series.

The parameters evolution of the third and the fourth series were comparable. After the first thermal cycle, the variation of $p_{f}$ with temperature falls within the parameter uncertainty domain and this parameter reached a stable value (Figure 19a, b). The evolution of $p_{l}$ was different, the temperature impact remained measurable while being totally reversible. Its change rate could be estimated to $1.5 \mathrm{kPa} /{ }^{\circ} \mathrm{C}$ in the studied temperature range $\left(1-40^{\circ} \mathrm{C}\right)$ (Figure $\left.19 \mathrm{c}, \mathrm{d}\right)$.

As with the previous test series, the variation of $E_{p}$ with temperature was lower than the other pressuremeter parameters (Figure 19e, f). The $E_{p}$ evolution for the third massif was erratic and inconsistent with the previous series and seems not to be relevant. On the contrary, a slight $E_{p}$ decrease, consistent with the previous tests, was measured when the fourth massif was heated.

\section{Discussion}

For the studied material at this initial state and under these test conditions, the creep pressure and the limit pressure decreased with increasing temperature which evidenced the thermal softening of the material. These results are consistent with the literature results obtained during oedometric or triaxial tests (Table 1).

The effect of first temperature cycle was more significant than the following cycles. The same phenomenon exists in the other domains of the soil mechanics. For example, during the investigation of the effect of cyclic wetting and drying on the characteristics of clays, Al-Homoud et al. (1995), Basma et al. (1996) and Nowamooz et 
al. (2013) showed that the first cycle caused the most reduction in swelling potential and observed that the amount of shrinkage for the first cycle was the largest and steadily decreased in later cycles. They explained it by more important modification in the clay structure after the first cycle than the subsequent cycles.

The temperature effect on the pressuremeter parameters could be due to the combination of the change in pore water viscosity and the expansion/contraction of the soil components which leads sometimes to the reorganization of the soil microstructure. Indeed, the decrease in pore water viscosity by heating can facilitate sliding between grains, thereby reducing the measured parameters. The heating of the massif from 20 to $40{ }^{\circ} \mathrm{C}$ led to the decrease in the studied parameters. It could be mainly due to the decrease in pore water viscosity and thermal softening and consequently it was reversible with cooling the massif to $20{ }^{\circ} \mathrm{C}$. On the contrary, the cooling of the massif from 20 to $1{ }^{\circ} \mathrm{C}$ led to the increase in the pressuremeter parameters and since the effect of cooling was partially reversible, it could be concluded that there was also the reorganization of the soil microstructure during the cooling which might be irreversible. This reorganization took place during the first cycle and the effect of the subsequent cycles was less significant. These hypotheses should be confirmed by an investigation on the modification of the microstructure of soil with heating and cooling.

\section{Conclusions}

The objective of this paper was to quantify the effect of cyclic temperature variations on soil parameters derived from the pressuremeter test used in pile design. As a result and for the first time, a device was developed to measure the mini-pressuremeter parameters in laboratory conditions and at different temperatures. The evolution of the pressuremeter modulus $\left(E_{p}\right)$, the creep pressure $\left(p_{f}\right)$ and the limit pressure $\left(p_{l}\right)$ was 
measured under imposed thermal conditions on a clayey compacted soil which has been selected for its high sensitivity to temperature variations.

The results of the mini-pressuremeter tests on the compacted illitic soil showed a decrease in the creep pressure and the limit pressure as temperature increased (thermal softening), while the variation of the pressuremeter modulus was less significant, this could be due to the well-known higher variability of this parameter. The results tended to show the reversibility of the temperature effects on the measured parameters for one heating cycle in the tested temperature range $\left(20-40{ }^{\circ} \mathrm{C}\right)$, whereas the effect of the first cooling phase to $1{ }^{\circ} \mathrm{C}$ was only partially reversible. For the following cycles, the effect of the temperature variation was lower. After more than one cycle, $p_{f}$ seemed to reach an equilibrium value independent of the temperature. The $p_{l}$ kept its temperature dependence beyond the $1^{\text {st }}$ cycle but its evolution $\left(1.5 \mathrm{kPa} /{ }^{\circ} \mathrm{C}\right)$ was reversible in the studied temperature range $\left(1-40{ }^{\circ} \mathrm{C}\right)$.

The limit pressure is the key parameter of calculating ultimate load of piles, so its variation with temperature should be taken into account to estimate the bearing capacity of geothermal piles particularly when they are built in temperature sensitive soils.

The trends demonstrated in this laboratory experiments study should be confirmed during full-scale in situ pressuremeter tests which need to be conducted in the proximity of an instrumented thermo-active pile.

\section{ACKNOWLEDGEMENTS}

This study was part of the GECKO research program funded by ANR. 


\section{BIBLIOGRAPHY}

AFNOR, 1993. NF P94-051 - Sols : reconnaissance et essais ; Détermination des limites d'Atterberg - Limite de liquidité à la coupelle- Limite de plasticité au rouleau. Association Française de Normalisation, Paris, France, p. 15.

AFNOR, 1996. NF P94-113 - Sols: reconnaissance et essais ; Essai de pénétration statique. Association Française de Normalisation, Paris, France, p. 16.

AFNOR, 1999. NF P94-093 - Sols : Reconnaissance et essais Détermination des références de compactage d 'un matériau. Essai Proctor Normal-Essai Proctor Modifié. Association Française de Normalisation, Paris, France, p. 18.

AFNOR, 2000. NF P94-110-1 - Sols : reconnaissance et essais Essai pressiométrique Ménard. Association Française de Normalisation, Paris, France, p. 44.

Akrouch, G.A., Sánchez, M., Briaud, J.-L., 2014. Thermo-mechanical behavior of energy piles in high plasticity clays. Acta Geotech. 9, 399-412.

Al-Homoud, A., Basma, A., Husein Malkawi, A., Al Bashabsheh, M., 1995. Cyclic Swelling Behavior of Clays. J. Geotech. Eng. 121, 562-565.

Arairo, J.B., Eslami, H., Rosin-Paumier, S., Abdallah, A., Masrouri, F., 2015. Experimental and numerical investigations of temperature effects on the pressuremeter parameters of a compacted illitic soil. Eng. Geol.

Basma, A. a., Al-Homoud, A.S., Husein Malkawi, A.I., Al-Bashabsheh, M. a., 1996. Swelling-shrinkage behavior of natural expansive clays. Appl. Clay Sci. 11, 211227.

Bourne-Webb, P.J., Amatya, B., Soga, K., Amis, T., Davidson, C., Payne, P., 2009. Energy pile test at Lambeth College, London: geotechnical and thermodynamic aspects of pile response to heat cycles. Géotechnique 59, 237-248.

Bourne-Webb, P.J., Soga, K., Amatya, B., 2013. A framework for understanding energy pile behaviour. Geotech. Eng. 166, 170-177.

Brandl, H., 2006. Energy foundations and other thermo-active ground structures. Géotechnique 56, 81-122.

Cekerevac, C., Laloui, L., 2004. Experimental study of thermal effects on the mechanical behaviour of a clay. Int. J. Numer. Anal. Methods Geomech. 28, 209228.

Eslami, H., Rosin-Paumier, S., Abdallah, A., Masrouri, F., 2015. Impact of temperature variation on penetration test parameters in compacted soils. Eur. J. Environ. Civ. Eng. 19, 628-648. 
Fromentin, A., Pahud, D., Laloui, L., Moreni, M., 1999. Pieux échangeurs: conception et règles de pré-dimensionnement. Rev. française génie Civ. 3, 387-421.

Graham, J., Tanaka, N., Crilly, T., Alfaro, M., 2001. Modified Cam-Clay modelling of temperature effects in clays. Can. Geotech. J. 38, 608-621.

GSHP Association, 2012. Thermal pile design, installation and materials standards, in: Ground Source Heat Pump Association, Milton Keynes. Ground Source Heat Pump Association, Milton Keynes, p. 82.

GTR, 2000. Réalisation des remblais et des couches de forme. Laboratoire Central des Ponts et Chaussées, Paris, p. 102.

Hueckel, T., Baldi, G., 1990. Thermoplasticity of saturated clays: experimental constitutive study. J. Geotech. Eng. 116, 1778-1796.

Laloui, L., Moreni, M., Vulliet, L., 2003. Comportement d'un pieu bi-fonction, fondation et échangeur de chaleur. Can. Geotech. J. 40, 388-402.

Lynch, F.L., 1997. Frio Shale Mineralogy and the Stoichiometry of the Smectite-toIllite Reaction: The Most Important Reaction in Clastic Sedimentary Diagenesis. Clays Clay Miner. 45, 618-631.

Marques, M., 2004. Viscous behaviour of St-Roch-de-1'Achigan clay, Quebec. Can. Geotech. J. 38, 25-38.

McCartney, J., LaHaise, D., LaHaise, T., Rosenberg, J., 2010a. Application of Geoexchange Experience to Geothermal Foundations. Art Found. Eng. Pract. (GSP 198) 411-422.

McCartney, J., Regueiro, R., Ko, H.Y., Pfeffer, T., Krarti, M., 2010b. Centrifuge Modeling of Soil-Structure Interaction in Geothermal Foundationse. NSF Report, University of Colorado, Boulder, CO., p. 22.

Nowamooz, H., Jahangir, E., Masrouri, F., 2013. Volume change behaviour of a swelling soil compacted at different initial states. Eng. Geol. 153, 25-34.

Péron, H., Knellwolf, C., Laloui, L., 2011. A method for the geotechnical design of heat exchanger piles, in: Proceedings of the American Society of Civil Engineers, GeoFrontiers. Dallas, USA, pp. 470-479.

Standard ASTM, 1995. D5778-95 Standard test method for performing electronic friction cone and piezocone penetration testing of soils. ASTM International, West Conshohocken, PA www. ASTM. org, p. 19.

Standard ASTM, 1999. D4719-00 Standard test method for Prebored Pressuremeter Testing in Soils. ASTM International, West Conshohocken, PA www. ASTM. org, p. 9. 
Standard ASTM, 2006. D2487 Standard practice for classification of soils for engineering purposes (Unified Soil Classification System). ASTM International, West Conshohocken, PA www. ASTM. org.

Tanaka, N., Graham, J., Crilly, T., 1997. Stress-strain behaviour of reconstituted illitic clay at different temperatures. Eng. Geol. 47, 339-350.

Tang, A.M., Pereira, J., Hassen, G., Yavari, N., 2013. Behavior of Heat-Exchanger Piles from Physical Modeling. Energy Geostructures 79-97.

Uchaipichat, A., Khalili, N., 2009. Experimental investigation of thermo-hydromechanical behaviour of an unsaturated silt. Géotechnique 59, 339-353. 
Table 1. Temperature effect on elastic domain (yield locus).

\begin{tabular}{ccccc}
\hline Authors & Studied soil & Measuring methods & Parameters & $\begin{array}{c}\text { Effect of } \\
\text { heating }\end{array}$ \\
\hline $\begin{array}{c}\text { Hueckel \& Baldi, } \\
(1990)\end{array}$ & $\begin{array}{c}\text { Saturated } \\
\text { silty clays }\end{array}$ & Drained triaxial shear test & $\mathrm{T}=20,90{ }^{\circ} \mathrm{C}$ & Contraction \\
\hline $\begin{array}{c}\text { Tanaka et al. } \\
(1997)\end{array}$ & $\begin{array}{c}\text { Saturated } \\
\text { illite }\end{array}$ & $\begin{array}{c}\text { Undrained triaxial shear } \\
\text { test }\end{array}$ & $\begin{array}{c}\mathrm{T}=28,65, \\
100{ }^{\circ} \mathrm{C}\end{array}$ & Contraction \\
\hline $\begin{array}{c}\text { Graham et al. } \\
(2001)\end{array}$ & $\begin{array}{c}\text { Saturated } \\
\text { illite }\end{array}$ & $\begin{array}{c}\text { Isotropic consolidation } \\
\text { (Triaxial) }\end{array}$ & $\begin{array}{c}\mathrm{T}=28,65, \\
100{ }^{\circ} \mathrm{C}\end{array}$ & Contraction \\
\hline Cekerevac \& & Saturated & Drained triaxial shear test & $\rho_{d=1.35 \mathrm{Mg} / \mathrm{m}^{3}}$ & Contraction \\
Laloui (2004) & kaolin & T $=22,60,90{ }^{\circ} \mathrm{C}$ & \\
\hline Marques et al., & Saturated & Undrained triaxial shear & $\rho \cong 1.5 \mathrm{Mg} / \mathrm{m}^{3}$ & Contraction \\
(2004) & clay & test and oedometric test & $\mathrm{T}=10,20,50{ }^{\circ} \mathrm{C}$ & \\
\hline Uchaipichat \& & Unsaturated & $\begin{array}{c}\text { Suction and temperature } \\
\text { controlled compression } \\
\text { Khalili (2009) }\end{array}$ & $\begin{array}{c}\rho_{d}=1.53 \mathrm{Mg} / \mathrm{m}^{3} \\
\mathrm{~T}=25,40,60{ }^{\circ} \mathrm{C}\end{array}$ & Contraction \\
& Bourke silt & shearts & & \\
\hline
\end{tabular}

Table 2. Details of mini-pressuremeter tests series.

\begin{tabular}{ccccl}
\hline Series & Temperature $\left({ }^{\circ} \mathrm{C}\right)$ & $\begin{array}{c}w_{\text {target }} \\
(\%)\end{array}$ & $\begin{array}{c}\rho_{\text {d.target }} \\
\left(\mathrm{Mg} / \mathrm{m}^{3}\right)\end{array}$ & \multicolumn{1}{c}{ Objective } \\
\hline $\begin{array}{c}\text { Preliminary } \\
\text { series }\end{array}$ & 20 & 31.3 & 1.29 & $\begin{array}{l}\text { To verify the efficiency of the compaction protocol } \\
\text { and massif homogeneity. } \\
\text { To test the possibility to perform 6 tests in a massif. }\end{array}$ \\
\hline $1^{\text {st }}$ series & $20-40-20$ & 31.3 & 1.29 & $\begin{array}{l}\text { To quantify the effect of heating: } \\
2 \text { tests at each temperature (20a-b, 40a-b, 20c-d) }\end{array}$ \\
\hline $2^{\text {nd }}$ series & $20-1-20$ & 31.3 & 1.29 & $\begin{array}{l}\text { To quantify the effect of cooling: } \\
\text { 2 tests at each temperature (20e-f, 1a-b, 20g-h) }\end{array}$ \\
\hline $3^{\text {rd }}$ series & $20-1-40-1-40-1-40-1$ & 31.3 & 1.29 & $\begin{array}{l}\text { To quantify the effect of temperature cycle: test } \\
\text { during the first 4 steps et des the last 2 steps (20i, 1c, } \\
\text { 40c, 1d, 40d, 1e) }\end{array}$ \\
\hline $4^{\text {th }}$ series & $20-1-40-1-40-1-40$ & 31.3 & 1.29 & $\begin{array}{l}\text { To quantify the effect of temperature cycle: 1 test at } \\
\text { each temperature (1f, 40e, 1g, 40f, 1h, 40g) }\end{array}$ \\
\hline
\end{tabular}


Table 3. Pressuremeter parameters for preliminary tests series.

\begin{tabular}{ccccccc}
\hline Test & $\begin{array}{c}\text { Temperature } \\
\left({ }^{\circ} \mathrm{C}\right)\end{array}$ & $w(\%)$ & $\rho_{d}\left(\mathrm{Mg} / \mathrm{m}^{3}\right)$ & $E_{p}(\mathrm{MPa})$ & $p_{f}(\mathrm{kPa})$ & $p_{l}(\mathrm{kPa})$ \\
\hline 1 & 20 & 31.6 & 1.30 & 4,02 & 250 & 467 \\
\hline 2 & 20 & 31.6 & - & 4,26 & 252 & 457 \\
\hline 3 & 20 & 31.8 & 1.26 & 4,02 & 220 & 409 \\
\hline 4 & 20 & 31.8 & 1.33 & 5,19 & 250 & 457 \\
\hline 5 & 20 & 31.7 & 1.29 & 4,97 & 242 & 447 \\
\hline
\end{tabular}

Table 4. Pressuremeter parameters for the $1^{\text {st }}$ series: heating cycle $\left(20-40-20{ }^{\circ} \mathrm{C}\right)$.

\begin{tabular}{ccccccc}
\hline Test & $\begin{array}{c}\text { Temperature } \\
\left({ }^{\circ} \mathrm{C}\right)\end{array}$ & $w(\%)$ & $\rho_{d}\left(\mathrm{Mg} / \mathrm{m}^{3}\right)$ & $p_{f}(\mathrm{kPa})$ & $p_{l}(\mathrm{kPa})$ & $E_{p}(\mathrm{MPa})$ \\
\hline $20 \mathrm{~b}$ & 20 & 31.0 & 1.31 & 194 & 355 & 3.54 \\
\hline $40 \mathrm{a}$ & 40 & 30.1 & 1.31 & 166 & 321 & 4.16 \\
\hline $40 \mathrm{~b}$ & 40 & 30.4 & 1.31 & 165 & 288 & 3.25 \\
\hline $20 \mathrm{c}$ & 20 & 31.1 & 1.31 & 197 & 379 & 4.54 \\
\hline $20 \mathrm{~d}$ & 20 & 31.1 & 1.32 & 178 & 352 & 3.89 \\
\hline
\end{tabular}

Table 5. Pressuremeter parameters for the $2^{\text {nd }}$ series: cooling cycle $\left(20-1-20{ }^{\circ} \mathrm{C}\right)$.

\begin{tabular}{ccccccc}
\hline Test & $\begin{array}{c}\text { Temperature } \\
\left({ }^{\circ} \mathrm{C}\right)\end{array}$ & $w(\%)$ & $\rho_{d}\left(\mathrm{Mg} / \mathrm{m}^{3}\right)$ & $p_{f}(\mathrm{kPa})$ & $p_{l}(\mathrm{kPa})$ & $E_{p}(\mathrm{MPa})$ \\
\hline $20 \mathrm{e}$ & 20 & 31.8 & 1.34 & 132 & 305 & 2.47 \\
\hline $20 \mathrm{f}$ & 20 & 32.0 & 1.26 & 133 & 246 & 2.28 \\
\hline $1 \mathrm{a}$ & 1 & 32.2 & 1.29 & 181 & 339 & 3.40 \\
\hline $1 \mathrm{~b}$ & 1 & 31.8 & 1.27 & 163 & 330 & 2.68 \\
\hline $20 \mathrm{~g}$ & 20 & 32.1 & 1.27 & 157 & 286 & 2.36 \\
\hline $20 \mathrm{~h}$ & 20 & 31.6 & 1.24 & 162 & 323 & 2.97 \\
\hline
\end{tabular}

Table 6. Variation of $p_{f}$ and $p_{l}$ for the first and second series of the tests.

\begin{tabular}{cccc}
\hline Initial temperature $\left({ }^{\circ} \mathrm{C}\right)$ & Final temperature $\left({ }^{\circ} \mathrm{C}\right)$ & $\Delta p_{f}(\%)$ & $\Delta p_{l}(\%)$ \\
\hline 20 & 1 & +30 & +21 \\
\hline 1 & 20 & -7 & -9 \\
\hline 20 & 40 & -15 & -14 \\
\hline 40 & 20 & +13 & +20 \\
\hline
\end{tabular}


Table 7. Pressuremeter parameters for the $3^{\text {rd }}$ series: temperature cycling (20-1-40-1-40$\left.1-40-1{ }^{\circ} \mathrm{C}\right)$.

\begin{tabular}{ccccccc}
\hline Test & $\begin{array}{c}\text { Temperature } \\
\left({ }^{\circ} \mathrm{C}\right)\end{array}$ & $w(\%)$ & $\rho_{d}\left(\mathrm{Mg} / \mathrm{m}^{3}\right)$ & $p_{f}(\mathrm{kPa})$ & $p_{l}(\mathrm{kPa})$ & $E_{p}(\mathrm{MPa})$ \\
\hline $20 \mathrm{i}$ & 20 & 31.4 & 1.25 & 103 & 240 & 5.51 \\
\hline $1 \mathrm{c}$ & 1 & 31.4 & 1.26 & 124 & 303 & 5.73 \\
\hline $40 \mathrm{c}$ & 40 & 32.1 & 1.25 & 125 & 236 & 7.68 \\
\hline $1 \mathrm{~d}$ & 1 & 31.7 & 1.25 & 123 & 337 & 4.16 \\
\hline $40 \mathrm{~d}$ & 40 & 31.5 & 1.28 & 143 & 270 & 6.85 \\
\hline $1 \mathrm{e}$ & 1 & 31.6 & 1.24 & 133 & 310 & 5.66 \\
\hline
\end{tabular}

Table 8. Pressuremeter parameters for the $4^{\text {th }}$ series: temperature cycling (20-1-40-1-40$\left.1-40{ }^{\circ} \mathrm{C}\right)$.

\begin{tabular}{ccccccc}
\hline Test & $\begin{array}{c}\text { Temperature } \\
\left({ }^{\circ} \mathrm{C}\right)\end{array}$ & $w(\%)$ & $\rho_{d}\left(\mathrm{Mg} / \mathrm{m}^{3}\right)$ & $p_{f}(\mathrm{kPa})$ & $p_{l}(\mathrm{kPa})$ & $E_{p}(\mathrm{MPa})$ \\
\hline $40 \mathrm{e}$ & 40 & 31.2 & 1.30 & 174 & 305 & 6.24 \\
\hline $1 \mathrm{~g}$ & 1 & 31.5 & 1.24 & 170 & 357 & 6.97 \\
\hline $40 \mathrm{f}$ & 40 & 31.2 & 1.28 & 170 & 307 & 6.18 \\
\hline $1 \mathrm{~h}$ & 1 & 31.0 & 1.24 & 160 & 344 & 6.16 \\
\hline $40 \mathrm{~g}$ & 40 & 31.1 & 1.25 & 153 & 276 & 5.76 \\
\hline
\end{tabular}



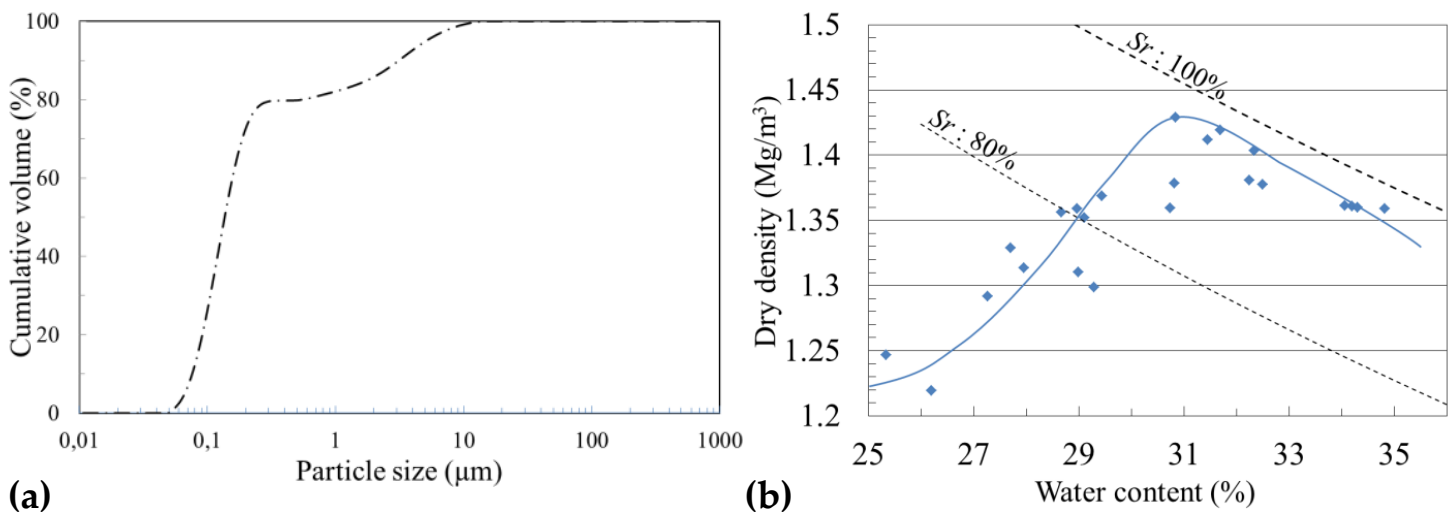

Figure 1 : Characteristic of the studied illitic soil: a) particle size distribution and b) compaction curve, $S_{r}$ : The degree of saturation. 

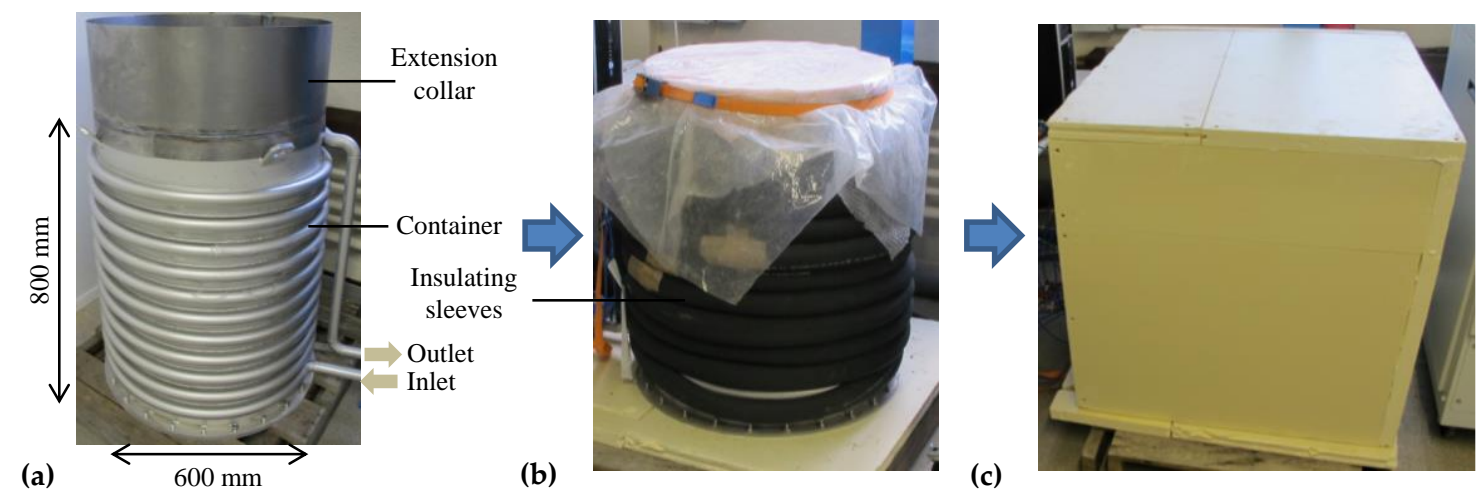

Figure 2: Thermo-regulated metric scale container: (a) cylindrical stainless steel container; (b) massif in the container isolated by insulating sleeves and plastic film;

(c) assembly in the box made of extruded polystyrene plates.
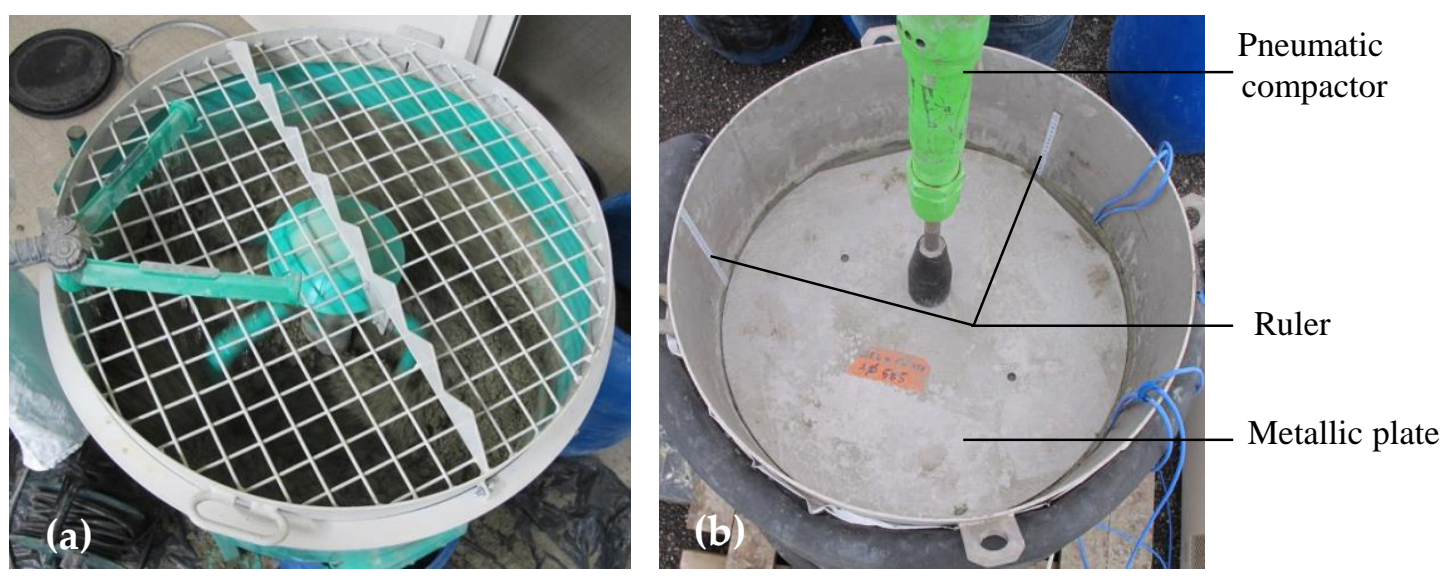

Figure 3. Sample preparation: (a) mixing; (b) compaction. 


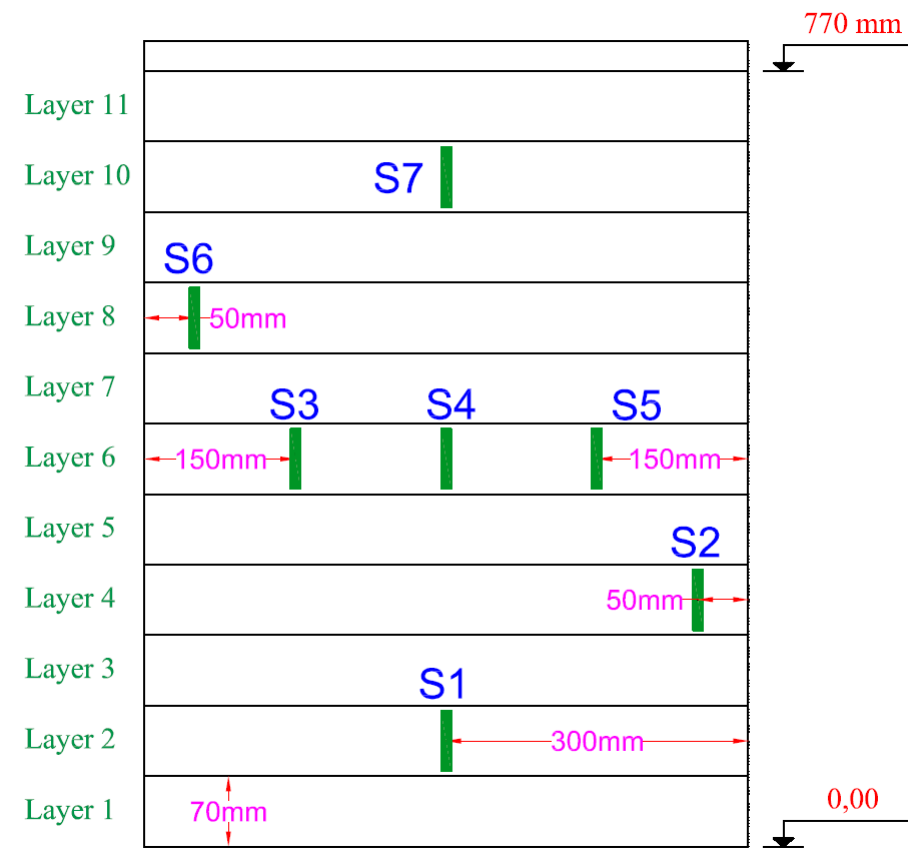

Figure 4. Position of the 7 thermal sensors in the massif.

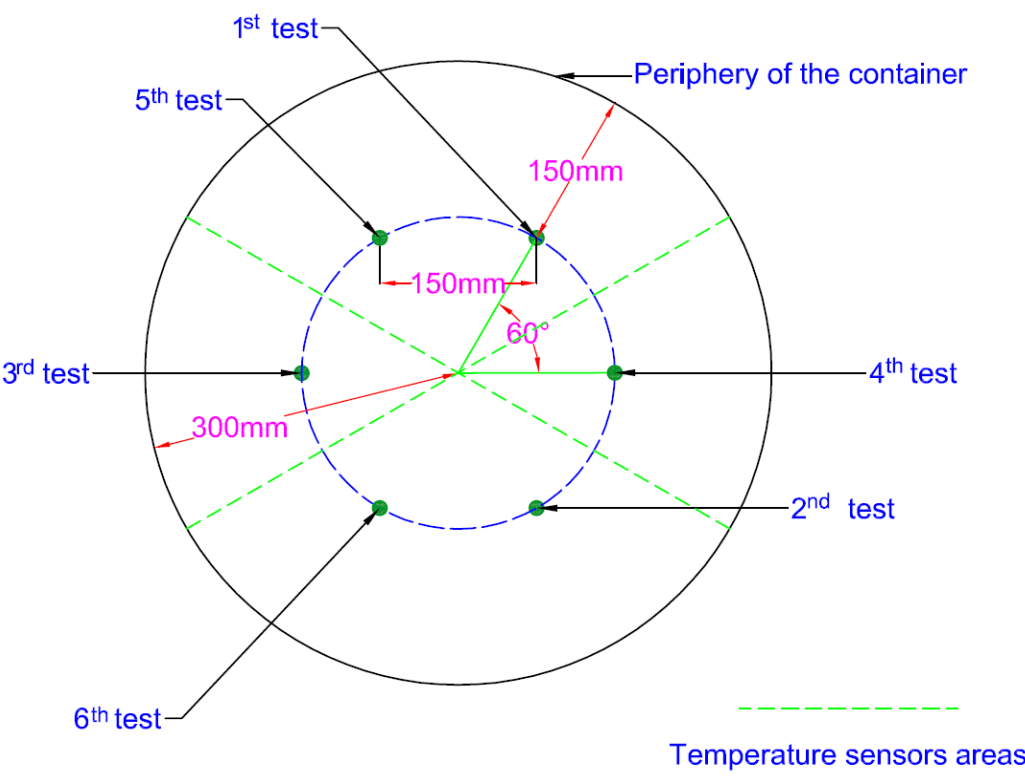

Figure 5. Positions of the test points and thermal sensors in the massif. 


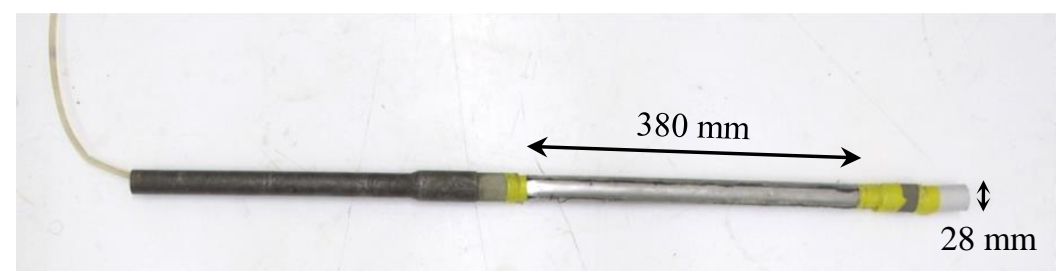

Figure 6. Mini-pressuremeter probe APAGEO®.

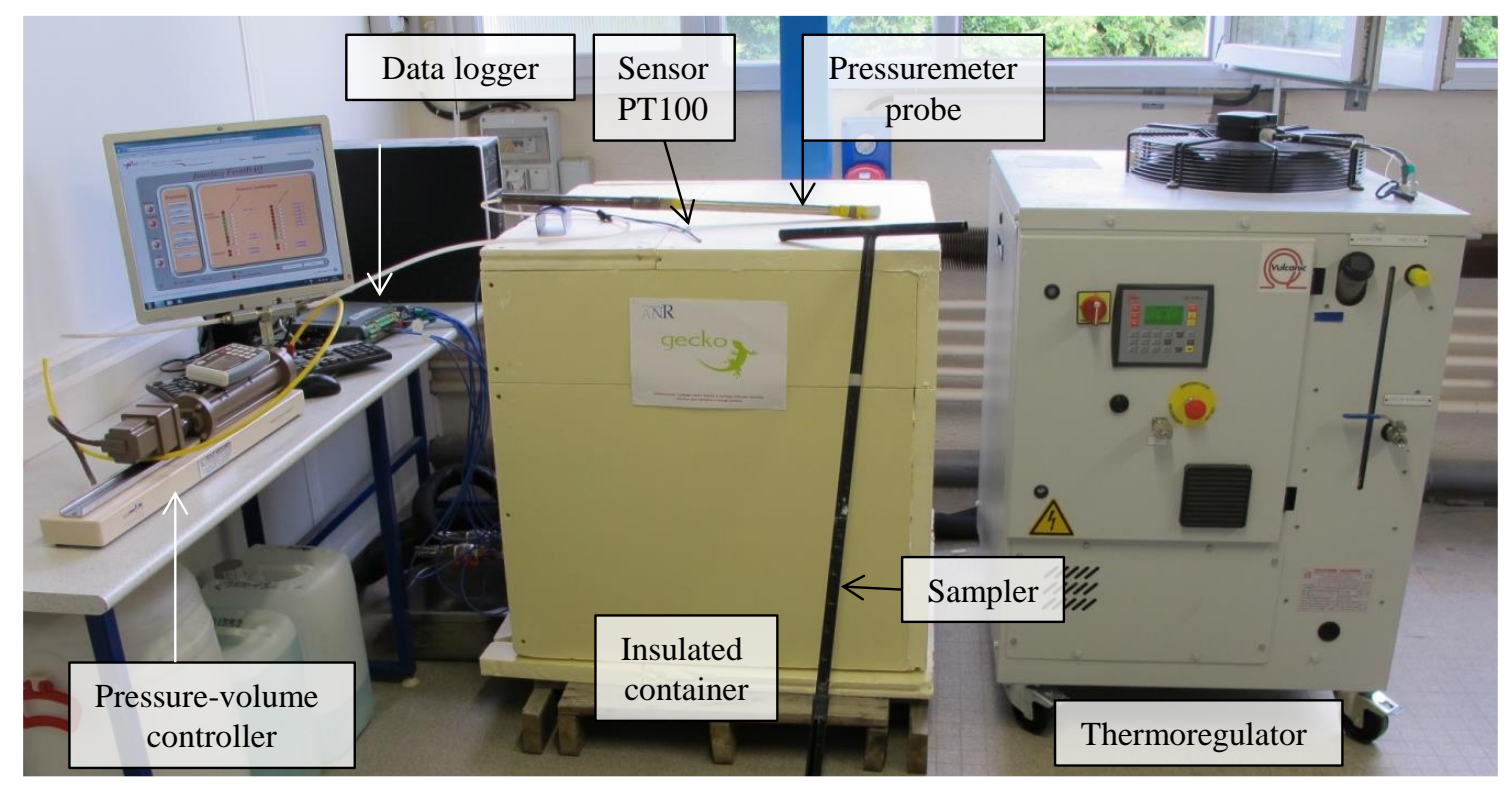

Figure 7. Elements of the developed experimental device. 

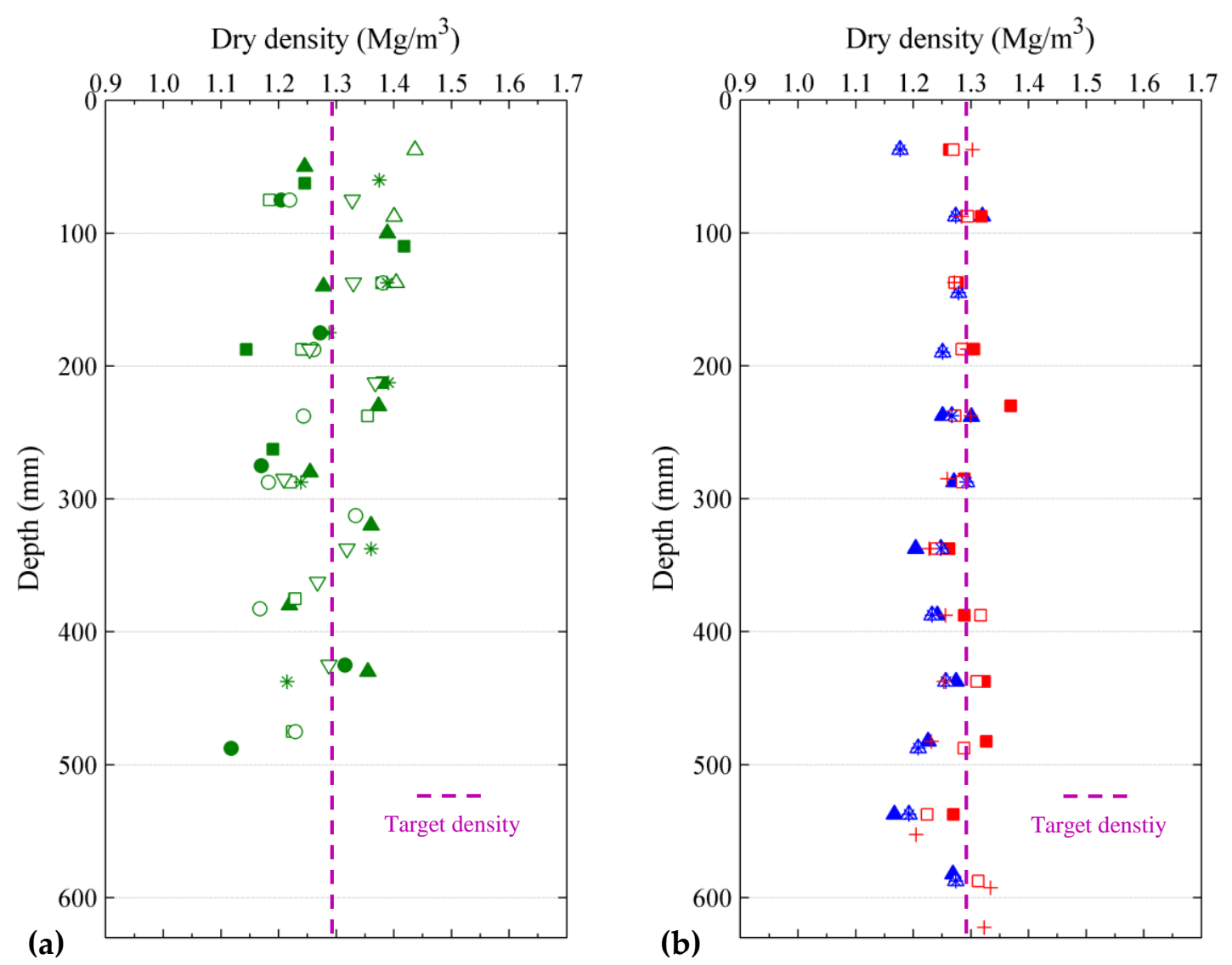

Figure 8. Dry density Profiles: (a) compaction in 8 layers (preliminary series); (b) compaction in 11 layers ( $4^{\text {th }}$ series). 


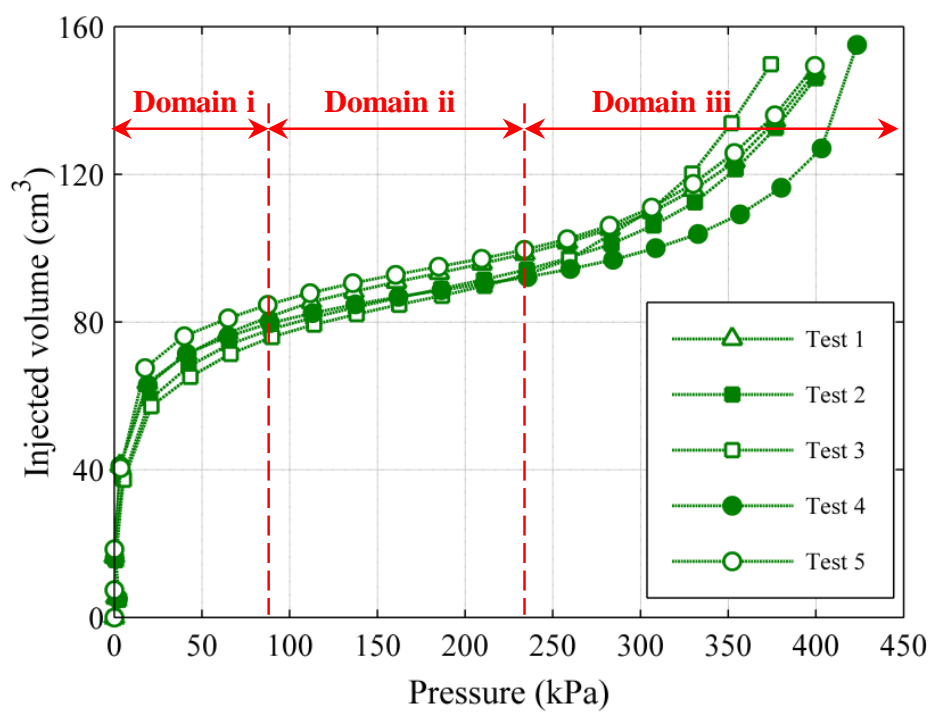

Figure 9. Pressuremeter curves: preliminary tests series. 


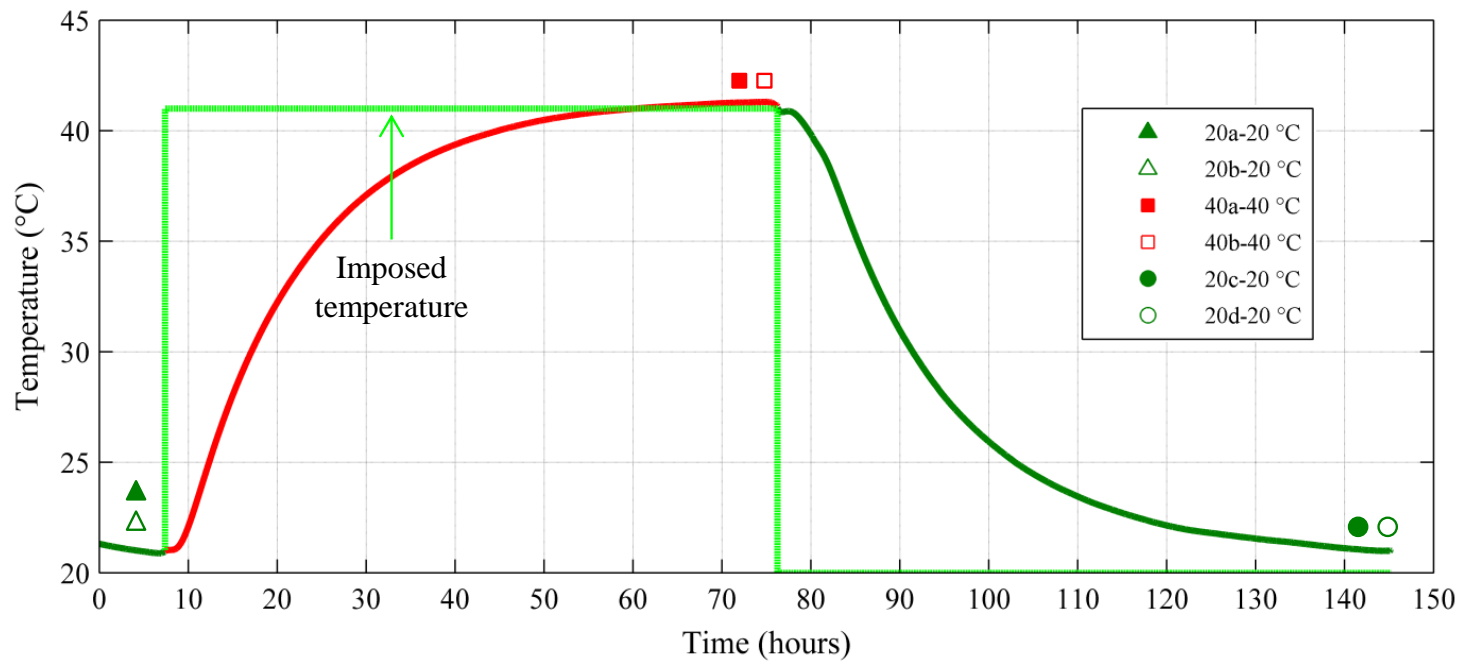

Figure 10. Temperature variation in the $1^{\text {st }}$ massif at $150 \mathrm{~mm}$ from the edge of the container (S5) and the chronology of the tests: heating-cooling cycle $\left(20-40-20{ }^{\circ} \mathrm{C}\right)$.

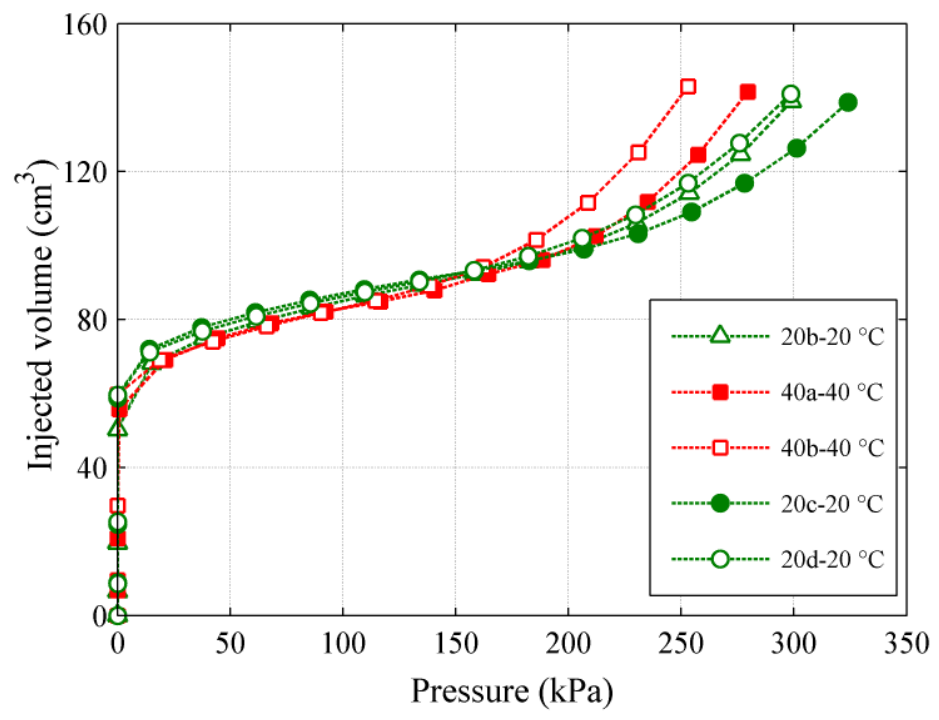

Figure 11. Pressuremeter curves for the $1^{\text {st }}$ series: heating-cooling cycle $\left(20-40-20{ }^{\circ} \mathrm{C}\right)$. 


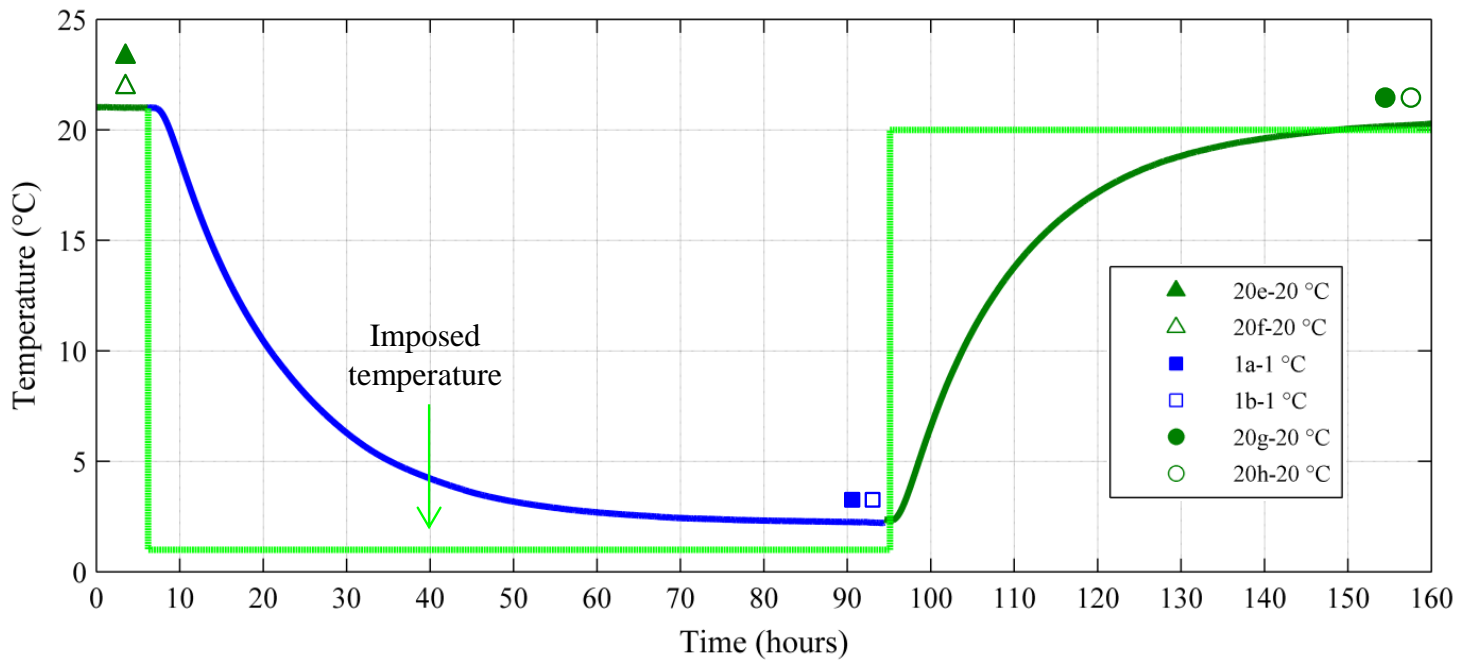

Figure 12. Temperature variation in the $2^{\text {nd }}$ massif at $150 \mathrm{~mm}$ from the edge of the container (S5) and the chronology of the tests cooling-heating cycle (20-1-20 $\left.{ }^{\circ} \mathrm{C}\right)$.

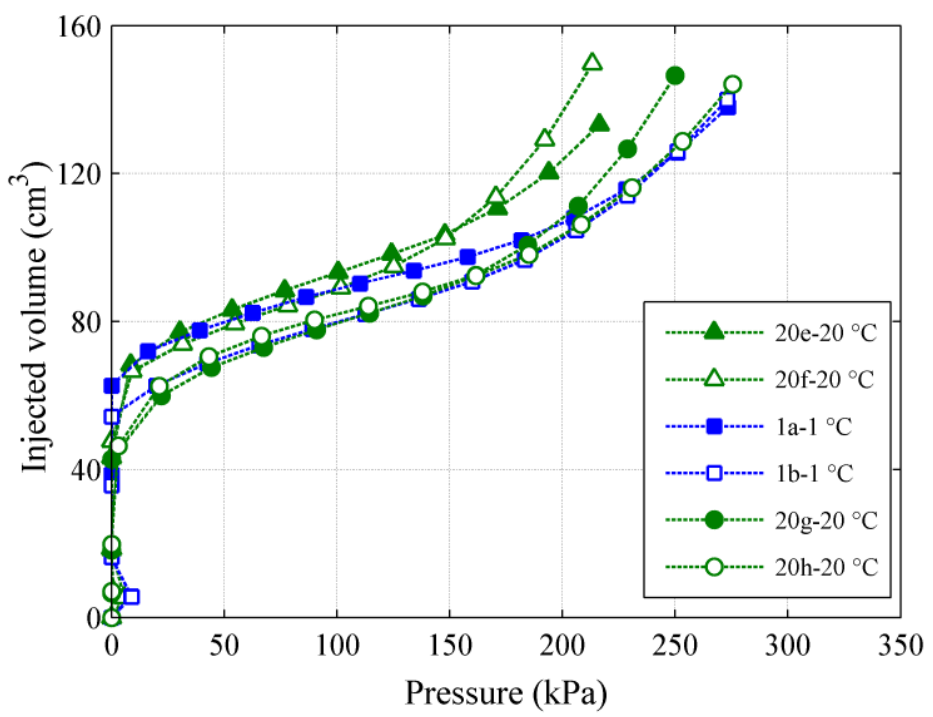

Figure 13. Pressuremeter curves for the $2^{\text {nd }}$ series: cooling-heating cycle $\left(20-1-20^{\circ} \mathrm{C}\right)$. 

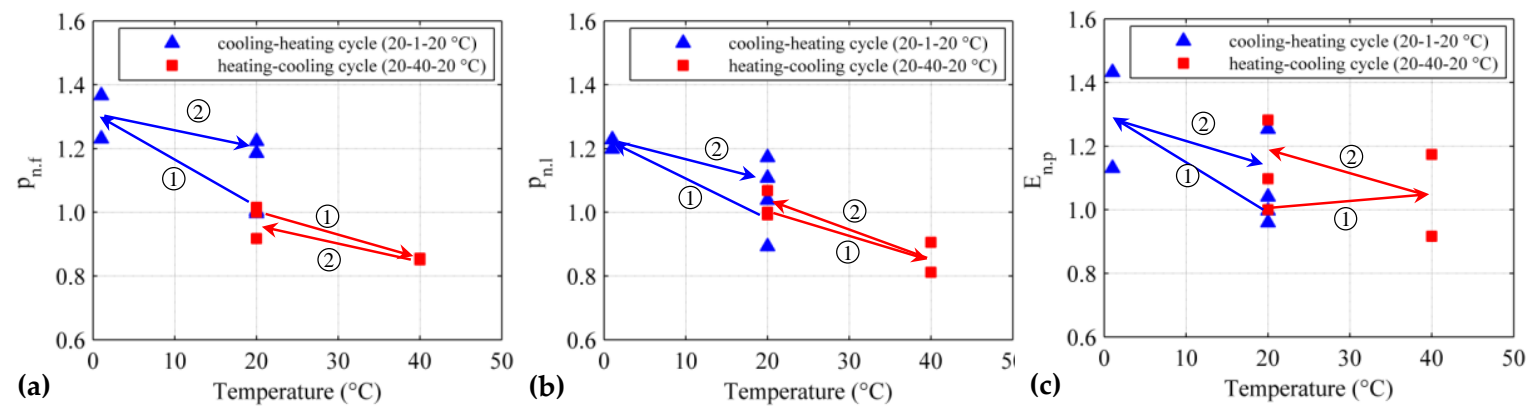

Figure 14. Variation of reduced pressuremeter parameters with temperature: (a) $p_{n . f}$; (b) $p_{n . l} ;$ (c) $E_{n . M .}$. 


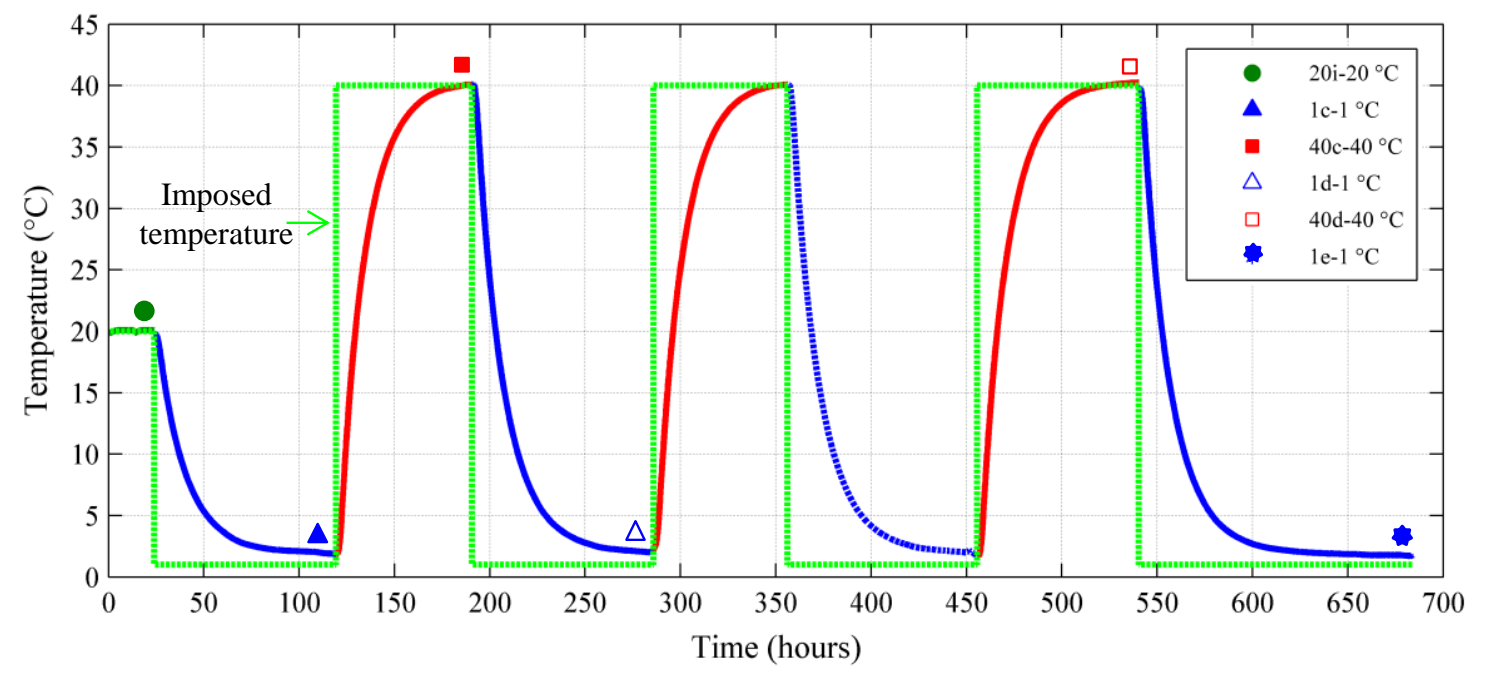

Figure 15. Temperature variation in the massif at $150 \mathrm{~mm}$ from the edge of the container and the chronology of the $3^{\text {rd }}$ series.

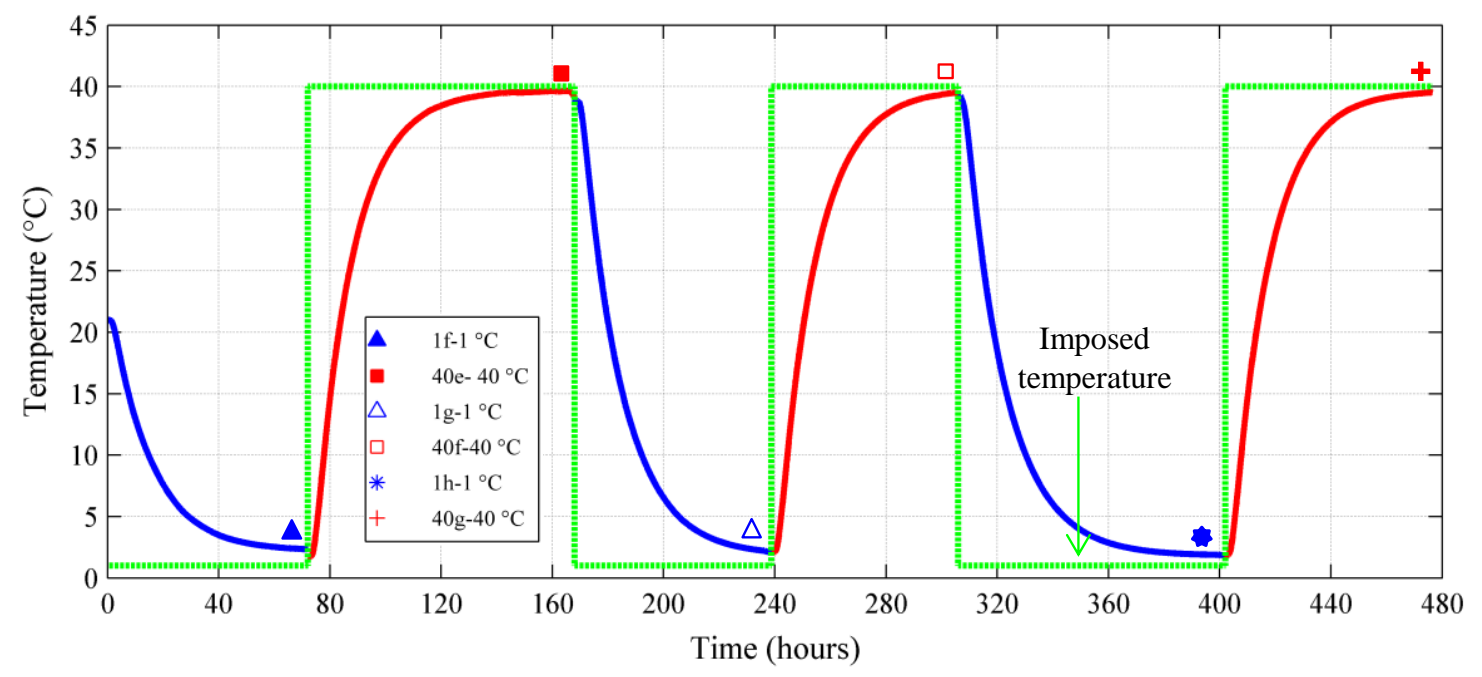

Figure 16. Temperature variation in the massif at $150 \mathrm{~mm}$ from the edge of the container and the chronology of the $4^{\text {th }}$ series. 


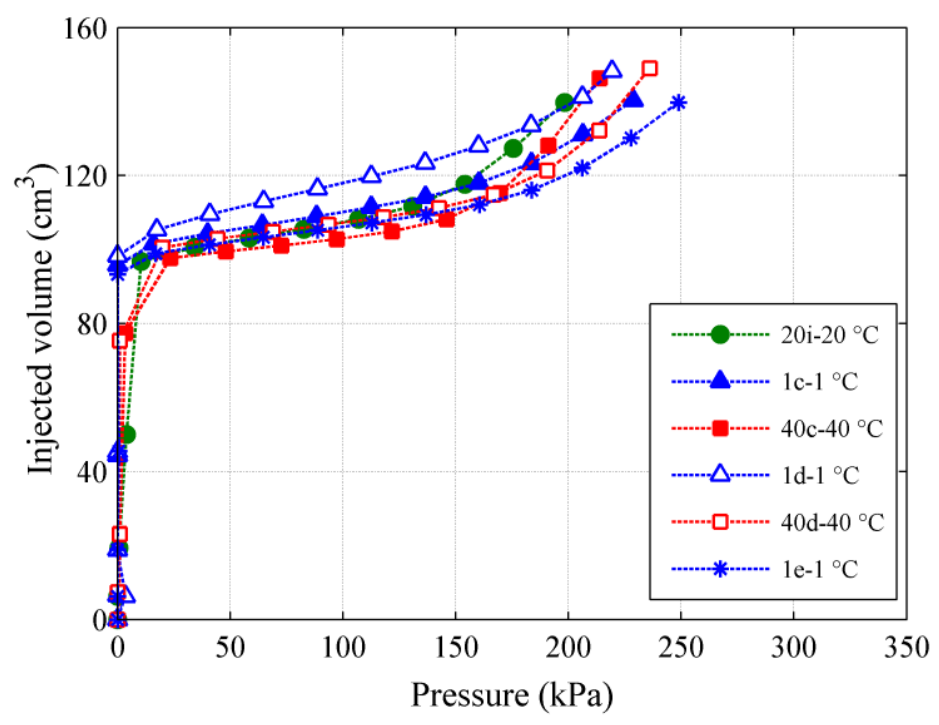

Figure 17. Pressuremeter curves of the $3^{\text {rd }}$ series tests.

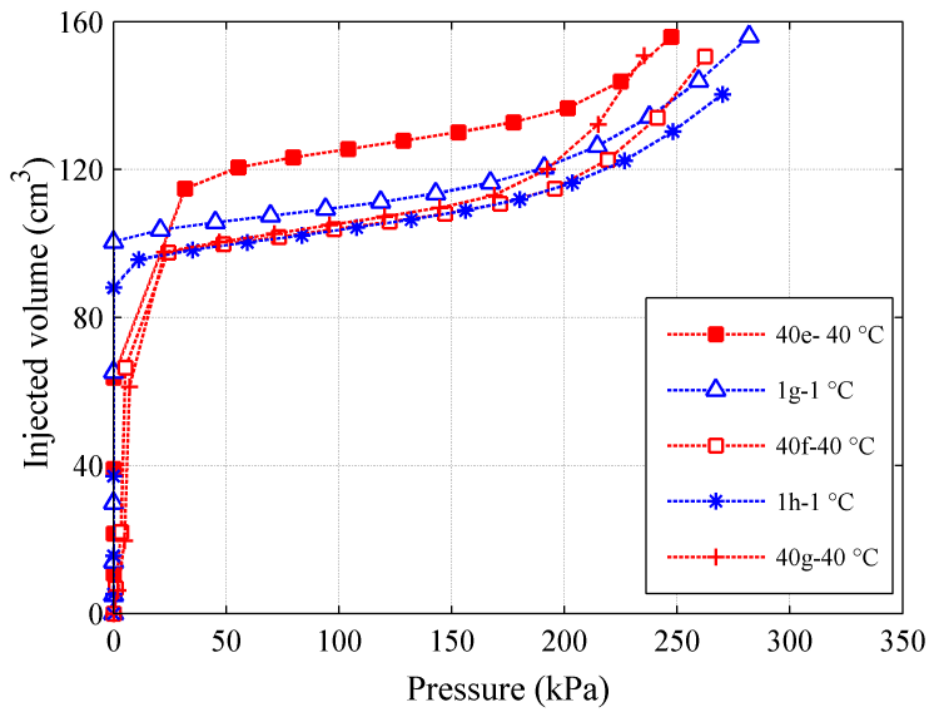

Figure 18. Pressuremeter curves of the $4^{\text {th }}$ series tests. 

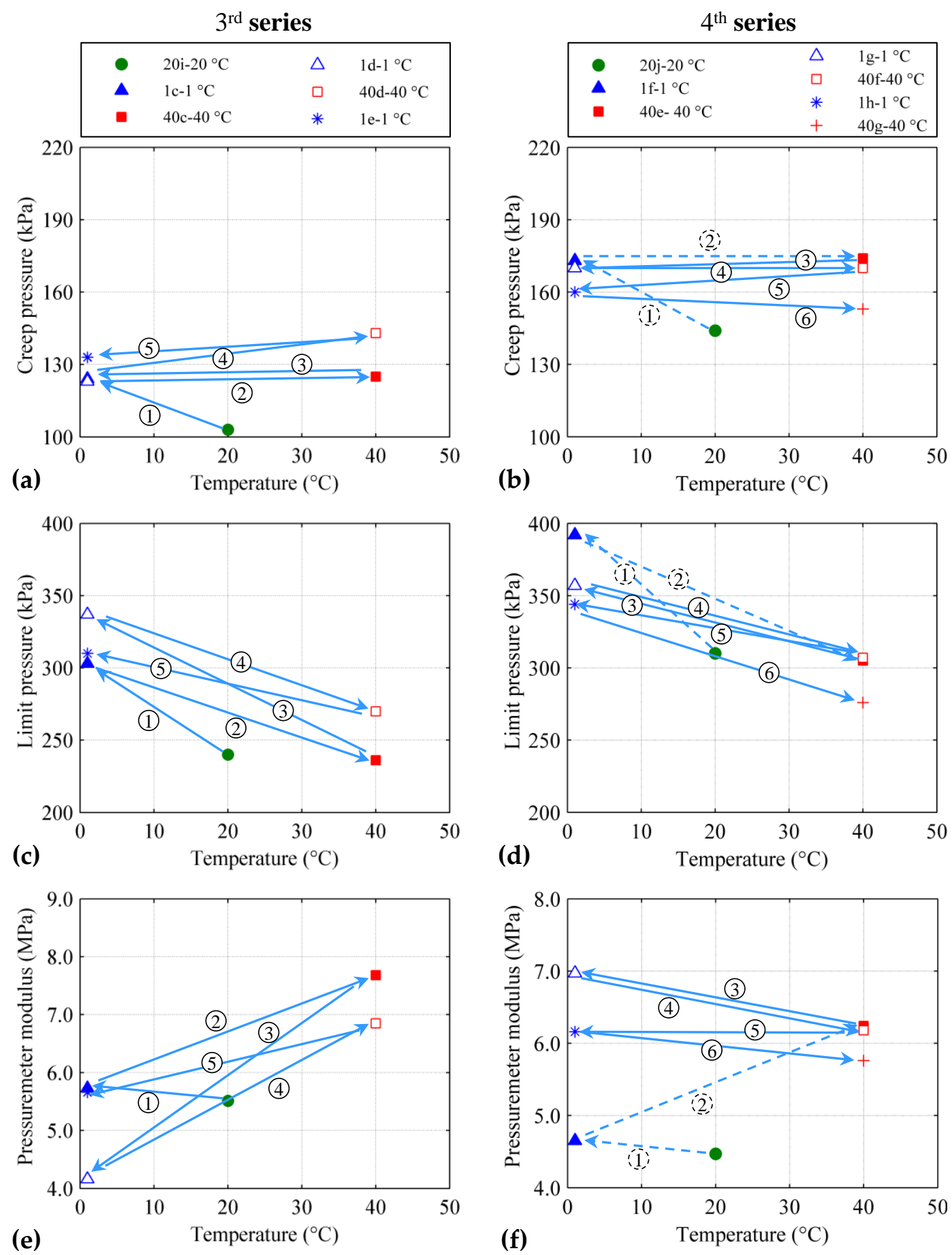

Figure 19. Variation of creep pressure $\left(p_{f}\right)(\mathrm{a}-\mathrm{b})$, limit pressure $\left(p_{l}\right)(\mathrm{c}-\mathrm{d})$ and pressuremeter modulus $\left(E_{p}\right)(\mathrm{e}-\mathrm{f})$ with temperature for the $3^{\text {rd }}$ and the $4^{\text {th }}$ test series. Dotted lines correspond to estimated parameters. 